\title{
PENGUATAN KETERAMPILAN BAHASA INGGRIS PEKERJA MIGRAN INDONESIA (PMI) CIREBON
}

Royani Afriani

IAIN Syekh Nurjati Cirebon

Maimunah

IAIN Syekh Nurjati Cirebon royani.afriani@syekhnurjati.ac.id

maimunah@gmail.com

- Received: 20 April 2020. • Accepted: $23 \quad$ Mei •Published online: 30 Juni 2020. 2020

\begin{abstract}
Penelitian ini dilakukan dalam rangka turut menyelesaikan satu dari beberapa persoalan yang dihadapi oleh Pekerja Migran Indonesia. Penelitian yang mengambil topic tentang Penguatan Keterampilan Bahasa Inggris bagi Calon Pekerja Migran Indonesia ini dilakukan di Pondok Pesantren Al-Quranniyah, Krangken, Indramayu. Penelitian dilakukan selama empat bulan dalam bentuk pendidikan dan pengajaran. Output dari kegiatan ini adalah meningkatkan kemampuan bahasa Inggris CPMI di Indramayu. Pihak-pihak yang terlibat dalam kegiatan ini adalah Dinas Ketenagakerjaan Indramayu dan Pengasuh, guru, ustadz, dan santri di Pondok Pesantren Al-Quranniyyah.
\end{abstract}

Kata kunci: Keterampilan Bahasa Inggris, Pekerja Migran. Indramayu

\section{Abstract}

This research is carried out in order to find an alternative solution to solve problems faced by Indonesian Migrant Workers. The title of the researchis Improving the Capability of Potential Indonesian Migrant Worker in English. The program was carried out at Al-Quraniyyah Islamic Boarding School, Krangken, Indramayu. The program was completed for four months. The output of this activity is the increasing skill in English of potential Migran worker in Indramayu. The parties involved in this activity are the Department of Manpower,Indramayu, Kyai or respected religious leader, teachers, and students at the Al-Quranniyyah Islamic Boarding School.

Keywords: English skill, Migrant Worker, Indramayu

\section{A. PENDAHULUAN}

Jaminan perlindungan tenaga kerja Indonesia yang mengadu nasib di negeri orang di nilai belum optimal. Padahal, UU No. 18 tahun 2017 tentang perlindungan Pekerja Migran Indonesia (PMI) sudah mengatur jaminan perlindungan TKI sejak keberangkatan hingga kepulangan ketanah air. Pemberian pelatihan dan penguatan ketrampilan berbahasa Inggris membantu dan memudahkan PMI berkomunikasi dengan orang asing di tempat mereka bekerja. Berdasarkan penelitian dan pengabdian sebelumnya, diketahui bahwa terdapat kebutuhan pelatihan penguatan kemampuan 
bahasa PMI secara berkelanjutan karena; Pertama, kemampuan bahasa tidak bisa dilakukan hanya satu kali dengan waktu 4 (empat) bulan. Kedua, pada program sebelumnya, target peserta hanya 30 peserta. Padahal, seperti yang kita tahu, jumlah PMI kita saat ini berdasarkan data yang ada di Indonesia berdasarkan hasil analisis data Survei Angkatan Kerja Nasional (Sakernas) tahun 2012 menunjukkan bahwa terdapat 6,5 juta pekerja migran Indonesia. Artinya, kebutuhan akan pelatihan peningkatan bahasa masih tinggi untuk dapat menyiapkan kemampuan bahasa PMI sebelum mereka diberangkatkan.

Pada tanggal 25 Oktober 2017 DPR telah mensahkan UU Perlindungan Pekerja Migran Indonesia Nomor 18 tahun 2017. Berdasarkan UU tersebut, definisi dari pekerja migran Indonesia adalah setiap warga negara Indonesia yang akan sedang atau telah melakukan pekerjaan dengan menerima upah di luar wilayah Republik Indonesia.

UU tersebut lahir sebagai upaya pemenuhan hak Pekerja Migran Indonesia untuk mendapatkan perlindungan dari pemerintah Republik Indonesia. Perlindungan pekerja migran Indonesia (PMI) merupakan segala upaya untuk melindungi kepentingan calon PMI dan keluarganya dalam mewujudkan terjaminnya pemenuhan haknya dalam keseluruhan kegiatan sebelum bekerja, selama bekerja dan setelah bekerja dalam aspek hukum, ekonomi dan sosial.

Selanjutnya tujuan dari perlindungan calon PMI adalah, (1) Menjamin pemenuhan dan penegakan hak asasi manusia sebagai warga negara dan PMI; dan (2) Menjamin perlindungan hukum, ekonomi dan sosial PMI dan keluarganya. Penguatan peran negara baik di tingkat pusat dan daerah menunjukkan komitmen negara untuk memberikan perlindungan kepada PMI dan penghormatan hak asasi manusia.

Tabel:

\begin{tabular}{|l|l|l|l|}
\hline \multicolumn{4}{|c|}{ Tugas dan Tanggung Jawab } \\
\hline Pemerintah Pusat & $\begin{array}{l}\text { Pemerintah } \\
\text { Provinsi }\end{array}$ & $\begin{array}{l}\text { Pemerintah } \\
\text { Kabupaten/Kota }\end{array}$ & Pemerintah Desa \\
\hline $\begin{array}{l}\text { Menjamin } \\
\text { perlindungan dan } \\
\text { pemenuhan hak } \\
\text { PMI }\end{array}$ & $\begin{array}{l}\text { Memberikan } \\
\text { perlindungan PMI } \\
\text { sebelum dan setelah } \\
\text { bekerja. }\end{array}$ & $\begin{array}{l}\text { Memberikan } \\
\text { perlindungan PMI } \\
\text { sebelum dan setelah } \\
\text { bekerja }\end{array}$ & $\begin{array}{l}\text { Melakukan } \\
\text { pemberdayaan } \\
\text { kepada calon PMI, } \\
\text { PMI dan } \\
\text { keluarganya }\end{array}$ \\
\hline $\begin{array}{l}\text { Mengatur, } \\
\text { membina, } \\
\text { melaksanakan dan } \\
\text { mengawasi } \\
\text { penyelengaraan } \\
\text { penempatan PMI }\end{array}$ & $\begin{array}{l}\text { Menerbitkan ijin } \\
\text { kantor cabang } \\
\text { perusahaan PMI } \\
\text { dan melaporkan } \\
\text { hasil evaluasinya } \\
\text { secara berjenjang }\end{array}$ & $\begin{array}{l}\text { Melaporkan hasil } \\
\text { evaluasi terhadap } \\
\text { perusahaan } \\
\text { penempatan PMI } \\
\text { kepada Pemprov. }\end{array}$ & $\begin{array}{l}\text { Memfasilitasi } \\
\text { pemenuhan } \\
\text { persyaratan } \\
\text { administrasi } \\
\text { kependudukan } \\
\text { calon PMI }\end{array}$ \\
\hline
\end{tabular}




\begin{tabular}{|l|l|l|l|}
\hline $\begin{array}{l}\text { mengembangkan } \\
\text { terpadu informasi }\end{array}$ & $\begin{array}{l}\text { membina, } \\
\text { melaksanakan dan } \\
\text { mengawasi } \\
\text { penyelenggaraan } \\
\text { penempatan PMI }\end{array}$ & $\begin{array}{l}\text { informasi dan } \\
\text { permintaan PMI } \\
\text { kepada masyarakat, } \\
\text { membuat basis data } \\
\text { PMI. }\end{array}$ & $\begin{array}{l}\text { memberikan } \\
\text { informasi dan } \\
\text { permintaan } \\
\text { pekerjaan dari } \\
\text { instansi }\end{array}$ \\
\hline $\begin{array}{l}\text { Melakukan } \\
\text { koordinasi kerja } \\
\text { sama antar instansi } \\
\text { dalam menanggapi } \\
\text { pengaduan dan } \\
\text { penanganan kasus } \\
\text { PMI }\end{array}$ & $\begin{array}{l}\text { Dapat membentuk } \\
\text { layanan terpadu } \\
\text { satu atap } \\
\text { penemapatan dan } \\
\text { perlindungan PMI. }\end{array}$ & $\begin{array}{l}\text { Dapat membentuk } \\
\text { layanan terpadu } \\
\text { satu atap } \\
\text { penempatan dan } \\
\text { perlindungan PMI }\end{array}$ & $\begin{array}{l}\text { Melakukan } \\
\text { verifikasi data dan } \\
\text { pencatatan calon } \\
\text { PMI }\end{array}$ \\
\hline $\begin{array}{l}\text { Mengurus } \\
\text { kepulangan PMI }\end{array}$ & $\begin{array}{l}\text { Menyediakan pos } \\
\text { bantuan dan } \\
\text { pelayanan di tempat } \\
\text { pemberangkatan } \\
\text { dan pemulangan } \\
\text { PMI }\end{array}$ & $\begin{array}{l}\text { Mengurus } \\
\text { kepulangan PMI }\end{array}$ & $\begin{array}{l}\text { Melakukan } \\
\text { pemantauan } \\
\text { keberangkatan dan } \\
\text { kepulangan PMI }\end{array}$ \\
\hline $\begin{array}{l}\text { Menyelenggarakan } \\
\text { pendidikan dan } \\
\text { melatihan kerja }\end{array}$ & $\begin{array}{l}\text { Menyelenggarakan } \\
\text { pendidikan dan } \\
\text { pelatihan kerja } \\
\text { pelatihan calon PMI } \\
\text { peranbinaan dan } \\
\text { pengawasan } \\
\text { terhadap lembaga } \\
\text { pendidikan dan } \\
\text { pelatihan kerja di } \\
\text { kabupaten/kota }\end{array}$ & \\
\hline
\end{tabular}

Berdasarkan table di atas dapat kita lihat bahwa pemenuhan hak pendidikan dan pelatihan kerja merupakan tugas pemerintah baik di tingkatan Kabupaten/Kota, Provinsi dan Pusat. Amanat undang-undang tersebut harus dilaksanakan agar dapat melindungi dan meminimalisir tingginya kasus kekerasan yang dialami oleh pekerja migrant kita di luar negeri.

Kegiatan ini dilaksanakan selama 4 (empat) bulan. Output yang dihasilkan dari kegiatan ini adalah meningkatkan kemampuan bahasa Inggris 30 orang calon Buruh Migran Indonesia di wilayah Indramayu.

Pekerja Migran Indonesia yang bekerja ke luar negeri dengan tujuan negaranegara berbahasa Inggris masih minim penguatan bahasa sebelum mereka diberangkatkan. Berdasarkan data yang ada, beberapa negara tujuan yang banyak dipilih oleh dari para calon Pekerja Migran Indonesia adalah Negara - Negara berbahasa Inggris, seperti Singapore, Hong Kong, serta Negara lainnya.

Meskipun beberapa Negara lain yang menjadi daerah tujuan utama bukan Negara berbahasa Inggris, sebagai bahasa Internasional yang paling banyak digunakan di dunia, 
para pekerja migrant tetap membutuhkannya. Oleh sebab itu, pelatihan ini bertujuan meningkatkan kemampuan bahasa Inggris calon PMI. Berikut ini adalah materi penguatan bahasa untuk Pekerja Migran Indonesia (PMI). Hal ini terangkum dalam Rumusan Masalah dari kegiatan ini yaitu Bagaimanakah tingkat penguasaan bahasa asing bagi PMI?

Tujuan Penelitian ini adalah (1) mendapatkan gambaran tentang pengetahuan dan kemampuan bahasa Asing calon Pekerja Migran Indonesia dan (2) Menyiapkan PMI yang lebih berkualitas melalui penguatan bahas asing sehingga melahirkan rasa percaya diri dan kekuatan diri para pekerja imigran Indonesia dalam bekerja di luar negeri. Maka, dengan memiliki kemapuan bahasa Inggris diharapkan para PMI lebih memiliki rasa kepercayaan diri. Sehingga, hasil secara tidak langsung yang diharapkan adalah meminimalisir berbagai persoalan PMI seperti kekerasan, penipuan dan tindakan lain yang merugikan PMI

\section{B. METODOLOGI PENELITIAN}

Metodologi yang digunakan dalam penelitian ini yaitu; membangun komunikasi dengan dinas dan pihak terkait. Dalam hal ini dengan Dinas Tenaga Kerja dan Transmigrasi Indramayu. Membangun komunikasi dengan Tokoh masyarakat setempat. Dalam hal ini adalah pimpinan Pondok Pesantren al-Quranniyah. Selanjutnya dilakukan Need Assessment: Need Assement adalah sebuah kegiatan yang dilakukan sebelum pelasanaan program. hasil dari kegiatan ini adalah terdatanya kebutuhan terkait penguatan bahasa asing calon peserta pelatihan. Pelatihan Penguatan Bahasa Inggris Calon BMI di Pondok Pesantren Al-Qur'anniyah. Evaluasi dan Monitoring. Monitoring dan evaluasi merupakan kegiatan yang dilakukan untuk melihat kendala dan masalah yang pada saat pelaksanaan penelitian. Juga melibatkan beberapa pihak sebagai berikut:

\section{A. Disnakertrans Indramayu}

Bentuk keterlibatan dari pihak Dinas adalah dalam hal kelengkapan data terkait Pekerja Migran Indonesia (PMI) di wilayah Indramayu. Tugas Pokok Kepala Bidang Penempatan Tenaga Kerja diantaranya adalah merumuskan dan melaksanakan kebijakan teknis di bidang penempatan tenaga kerja dalam negeri, penempatan dan perlindungan tenaga kerja luar negeri serta perluasan kesempatan kerja. Selain itu, Kepala Bidang Penempatan Tenaga Kerja juga meliputi: 
1) perumusan kebijakan teknis di bidang penempatan tenaga kerja dalam negeri, penempatan dan perlindungan tenaga kerja luar negeri serta perluasan kesempatan kerja;

2) pelaksanaan kebijakan teknis di bidang penempatan tenaga kerja dalam negeri, penempatan dan perlindungan tenaga kerja luar negeri serta perluasan kesempatan kerja;

3) pembinaan teknis di bidang penempatan tenaga kerja dalam negeri, penempatan dan perlindungan tenaga kerja luar negeri serta perluasan kesempatan kerja;

4) pelaksanaan koordinasi pemberian dan penyebarluasan informasi pasar kerja dalam pelayanan antar kerja kepada pencari kerja dan pemberi kerja serta perluasan kesempatan kerja kepada masyarakat;

5) pelaksanaan koordinasi penyuluhan dan bimbingan jabatan dalam pelayanan antar kerja serta perluasan kesempatan kerja kepada masyarakat;

6) pelaksanaan koordinasi perantaraan kerja dalam pelayanan antar kerja serta perluasan kesempatan kerja kepada masyarakat;

7) pelaksanaan verifikasi penerbitan izin kepada lembaga penempatan tenaga kerja swasta;

8) pelaksanaan promosi penyebarluasan informasi syarat-syarat dan mekanisme bekerja ke luar negeri kepada masyarakat;

9) pelaksanaan koordinasi pendaftaran, perekrutan dan seleksi calon Tenaga Kerja Indonesia (TKI);

10) dll

Oleh karena itu, pelibatan Kepala Penempatan Tenaga Kerja menjadi sangat penting dalam hal ini berkaitan dengan informasi terbaru tentang jumlah CPMI dan Negara yang menjadi tujuan CPMI. Penempatan Tenaga Kerja, membawahkan (1) Seksi Penempatan Tenaga Kerja Dalam Negeri; (2) SeksiPenempatan dan Perlindungan Tenaga Kerja Luar Negeri; dan (3) Seksi Perluasan Kesempatan Kerja.

\section{B. Pengasuh PP. AL-QUR'ANNIYAH Indramayu}

Penelitian penguatan Bahasa Inggris bagi calon PMI dilaksanakan di Pondok pesantren yang terletak di Desa dukuh Jati, Kecamatan Krangkeng, Kabupaten Indramayu. Pondok pesantren ini didirikan tahun 1965. Keterbukaan pihak Pesantren, khususnya Pengasuh Pondok Pesantren, KH. Zuhri memungkinkan adanya kerjasama untuk pelaksanaan penelitian penguatan bahasa dalam hal pengorganisiran peserta, tempat, dan lainnya. 


\section{TEMUAN DAN PEMBAHASAN}

Indramayu merupakan salah satu wilayah Kerisedenan Cirebon. Indramayu merupakan salah satu daerah pengirim PMI tertinggi di Indonesia. Penguatan pelatihan bahasa Inggris kepada masyarakat dilakukan di Pondok Pesantren Al-Qur'aniyyah. Pemilihan Pondok Pesantren sebagai tempat pelaksanaan penelitian karena lokasi pesantren yang berada di tengah-tengah masyarakat, terletak di Krangken Indramayu. Daerah ini merupakan salah satu wilayah dengan jumlah PMI tertinggi di wilayah Indramayu seperti yang terlibat berdasarkan table di bawah ini

\section{REKAPITULASI PENDAFTARAN CPMI}

TAHUN 2017

PER KECAMATAN

KABUPATEN INDRAMAYU

\begin{tabular}{|c|c|c|c|c|}
\hline NO & KECAMATAN & $\mathbf{L}$ & $\mathbf{P}$ & JUMLAH \\
\hline 1 & ANJATAN & 47 & 755 & 802 \\
\hline 2 & ARAHAN & 24 & 265 & 289 \\
\hline 3 & BALONGAN & 101 & 586 & 687 \\
\hline 4 & BANGODUA & 30 & 320 & 350 \\
\hline 5 & BONGAS & 27 & 442 & 469 \\
\hline 6 & CANTIGI & 37 & 294 & 331 \\
\hline 7 & CIKEDUNG & 20 & 320 & 340 \\
\hline 8 & GABUSWETAN & 33 & 370 & 403 \\
\hline 9 & GANTAR & 7 & 190 & 197 \\
\hline 10 & HAURGEULIS & 17 & 368 & 385 \\
\hline 11 & INDRAMAYU & 512 & 836 & 1,348 \\
\hline 12 & JATIBARANG & 61 & 716 & 777 \\
\hline 13 & JUNTINYUAT & 182 & 1,371 & 1,553 \\
\hline 14 & KANDANGHAUR & 42 & 606 & 648 \\
\hline 15 & KARANGAMPEL & 66 & 695 & 761 \\
\hline
\end{tabular}


Royani Afriani, Maimunah

\begin{tabular}{|c|c|c|c|c|}
\hline 16 & KEDOKANBUNDER & 43 & 512 & 555 \\
\hline 17 & KERTASEMAYA & 42 & 715 & 757 \\
\hline 18 & KRANGKENG & 55 & 824 & 879 \\
\hline 19 & KROYA & 24 & 420 & 444 \\
\hline 20 & LELEA & 56 & 450 & 506 \\
\hline 21 & LOHBENER & 46 & 568 & 614 \\
\hline 22 & LOSARANG & 22 & 402 & 424 \\
\hline 23 & PASEKAN & 22 & 155 & 177 \\
\hline 24 & PATROL & 18 & 479 & 497 \\
\hline 25 & SINDANG & 32 & 357 & 389 \\
\hline 26 & SLIYEG & 81 & 836 & 917 \\
\hline 27 & SUKAGUMIWANG & 29 & 471 & 500 \\
\hline 28 & SUKRA & 18 & 457 & 475 \\
\hline 29 & TERISI & 23 & 429 & 452 \\
\hline 30 & TUKDANA & 47 & 699 & 746 \\
\hline 31 & WIDASARI & 25 & 393 & 418 \\
\hline & JUMLAH & 1,789 & 16,301 & 18,090 \\
\hline
\end{tabular}

REKAPITULASI PENDAFTARAN CPMI

TAHUN 2018

PER KECAMATAN

KABUPATEN INDRAMAYU

\begin{tabular}{|l|l|l|l|c|}
$\mathbf{N O}$ & KECAMATAN & $\mathbf{L}$ & $\mathbf{P}$ & JML \\
\hline $\mathbf{1}$ & ANJATAN & 155 & 850 & $\mathbf{1 , 0 0 5}$ \\
\hline $\mathbf{2}$ & ARAHAN & 63 & 402 & $\mathbf{4 6 5}$ \\
\hline $\mathbf{3}$ & BALONGAN & 224 & 573 & $\mathbf{7 9 7}$ \\
\hline $\mathbf{4}$ & BANGODUA & 83 & 394 & $\mathbf{4 7 7}$ \\
\hline $\mathbf{5}$ & BONGAS & 77 & 515 & $\mathbf{5 9 2}$ \\
\hline $\mathbf{6}$ & CANTIGI & 111 & 357 & $\mathbf{4 6 8}$ \\
\hline
\end{tabular}


Royani Afriani, Maimunah

\begin{tabular}{|l|l|l|l|r|}
$\mathbf{7}$ & CIKEDUNG & 45 & 377 & $\mathbf{4 2 2}$ \\
\hline $\mathbf{8}$ & GABUSWETAN & 83 & 473 & $\mathbf{5 5 6}$ \\
\hline $\mathbf{9}$ & GANTAR & 30 & 219 & $\mathbf{2 4 9}$ \\
\hline $\mathbf{1 0}$ & HAURGEULIS & 62 & 428 & $\mathbf{4 9 0}$ \\
\hline $\mathbf{1 1}$ & INDRAMAYU & 125 & 673 & $\mathbf{7 9 8}$ \\
\hline $\mathbf{1 2}$ & JATIBARANG & 113 & 789 & $\mathbf{9 0 2}$ \\
\hline $\mathbf{1 3}$ & JUNTINYUAT & 333 & 1449 & $\mathbf{1 , 7 8 2}$ \\
\hline $\mathbf{1 4}$ & KANDANGHAUR & 111 & 640 & $\mathbf{7 5 1}$ \\
\hline $\mathbf{1 5}$ & KARANGAMPEL & 122 & 736 & $\mathbf{8 5 8}$ \\
\hline $\mathbf{1 6}$ & KEDOKANBUNDER & 97 & 663 & $\mathbf{7 6 0}$ \\
\hline $\mathbf{1 7}$ & KERTASEMAYA & 216 & 760 & $\mathbf{9 7 6}$ \\
\hline $\mathbf{1 8}$ & KRANGKENG & 125 & 929 & $\mathbf{1 , 0 5 4}$ \\
\hline $\mathbf{1 9}$ & KROYA & 76 & 679 & $\mathbf{7 5 5}$ \\
\hline $\mathbf{2 0}$ & LELEA & 96 & 564 & $\mathbf{6 6 0}$ \\
\hline $\mathbf{2 1}$ & LOHBENER & 92 & 684 & $\mathbf{7 7 6}$ \\
\hline $\mathbf{2 2}$ & LOSARANG & 50 & 524 & $\mathbf{5 7 4}$ \\
\hline $\mathbf{2 3}$ & PASEKAN & 45 & 189 & $\mathbf{2 3 4}$ \\
\hline $\mathbf{2 4}$ & PATROL & 87 & 711 & $\mathbf{7 9 8}$ \\
\hline $\mathbf{2 5}$ & SINDANG & 70 & 442 & $\mathbf{5 1 2}$ \\
\hline $\mathbf{2 6}$ & SLIYEG & 211 & 1019 & $\mathbf{1 , 2 3 0}$ \\
\hline $\mathbf{2 7}$ & SUKAGUMIWANG & 77 & 494 & $\mathbf{5 7 1}$ \\
\hline $\mathbf{2 8}$ & SUKRA & 43 & 629 & $\mathbf{6 7 2}$ \\
\hline $\mathbf{2 9}$ & TERISI & 56 & 552 & $\mathbf{6 0 8}$ \\
\hline $\mathbf{3 0}$ & TUKDANA & $\mathbf{3 3 1 8}$ & 886 & $\mathbf{1 , 0 6 9}$ \\
\hline $\mathbf{3 1}$ & WIDASARI & $\mathbf{1 9 0 8 0}$ & $\mathbf{2 2 , 3 9 8}$ \\
\hline & JUMLAH & & & \\
\hline
\end{tabular}

Berdasarkan table di atas dapat di ketahui bahwa Krangkeng merupakan salah satu daerah dengan jumlah PMI tertinggi di wilayah Indramayu. Sebanyak 55 PMI lakilaki dan 824 PMI perempuan di tahun 2017 menjadi pekerja migran. Selanjutnya, terjadi peningkatan pada tahun 2018 sebanyak 125 PMI laki-laki dan 925 PMI perempuan.

Masih berdasarkan data di atas, belum terjadi perubahan tren tentang tingginya jumlah perempuan yang menjadi pekerja migrant. Pada tahun 2017, jumlah laki-laki yang menjadi PMI sebanyak 1.787 dan perempuan sebanyak 16.301. Di tahun 
Royani Afriani, Maimunah

selanjutnya, pada tahun 2018, jumlah laki-laki naik menjadi 3.318 dan peningkatan juga terjadi pada perempuan yang menjadi PMI yaitu sebesar 19.080.

Jika tren tentang jumlah laki-laki dan perempuan yang menjadi PMI belum mengalami perubahan, hal yang sebaliknya terjadi pada tren tentang negara tujuan PMI. Sejak diterapkannya moratorium untuk sektor non-formal di beberapa negara di Timur Tengah, jumlah PMI yang menjadikan negara Timur Tengah sebagai negara tujuan juga menjadi turun. Hal tersebut dapat terlihat pada table di bawah ini.

\section{REKAPITULASI PENDAFTARAN CTKI}

PER NEGARA

KABUPATEN INDRAMAYU

TAHUN 2017

\begin{tabular}{|l|l|r|r|r|}
$\mathbf{N O}$ & NEGARA & \multicolumn{1}{|l|}{ L } & \multicolumn{1}{|l|}{ JUMLAH } \\
\hline $\mathbf{1}$ & BRUNAI DARUSSALAM & 55 & 100 & 155 \\
\hline $\mathbf{2}$ & HONG KONG & 1 & 3,904 & 3,905 \\
\hline $\mathbf{3}$ & MALAYSIA & 491 & 2,049 & 2,540 \\
\hline $\mathbf{4}$ & SINGAPURA & 3 & 2,354 & 2,357 \\
\hline $\mathbf{5}$ & TAIWAN & 769 & 7,686 & 8,455 \\
\hline $\mathbf{6}$ & KOREA SELATAN & 467 & 157 & 624 \\
\hline $\mathbf{7}$ & JEPANG & 3 & 51 & 54 \\
\hline & JUMLAH & $\mathbf{1 , 7 8 9}$ & $\mathbf{1 6 , 3 0 1}$ & $\mathbf{1 8 , 0 9 0}$ \\
\hline
\end{tabular}

TAHUN 2018

PER NEGARA

KABUPATEN INDRAMAYU

\begin{tabular}{|l|l|l|l|r|}
$\mathbf{N O}$ & NEGARA & $\mathbf{L}$ & $\mathbf{P}$ & \multicolumn{1}{|l|}{ JML } \\
\hline $\mathbf{1}$ & BRUNAI DARUSSALAM & 98 & 197 & $\mathbf{2 9 5}$ \\
\hline $\mathbf{2}$ & HONG KONG & 41 & 4283 & $\mathbf{4 , 3 2 4}$ \\
\hline $\mathbf{3}$ & MALAYSIA & 688 & 2202 & $\mathbf{2 , 8 9 0}$ \\
\hline $\mathbf{4}$ & SINGAPURA & 13 & 2880 & $\mathbf{2 , 8 9 3}$ \\
\hline $\mathbf{5}$ & TAIWAN & 1949 & 9370 & $\mathbf{1 1 , 3 1 9}$ \\
\hline $\mathbf{6}$ & KOREA SELATAN & 510 & 64 & $\mathbf{5 7 4}$ \\
\hline $\mathbf{7}$ & SAUDI ARABIA & 4 & 10 & $\mathbf{1 4}$ \\
\hline $\mathbf{8}$ & UNITED ARAB EMIRATES & 3 & 5 & $\mathbf{8}$ \\
\hline $\mathbf{9}$ & BAHRAIN & 3 & 66 & $\mathbf{6 9}$ \\
\hline $\mathbf{1 0}$ & OMAN & 0 & 1 & $\mathbf{1}$ \\
\hline $\mathbf{1 1}$ & KUWAIT & 9 & 2 & $\mathbf{1 1}$ \\
\hline
\end{tabular}


Berbagai kasus kekerasan hingga eksekusi mati PRT migran Indonesia di Arab Saudi membuat Pemerintah Indonesia kembali mengeluarkan kebijakan moratorium penghentian pengiriman TKI khususnya PRT migran ke 21 negara di Timur Tengah yang mulai diberlakukan pada 1 Juli 2015 melalui Keputusan Menteri Tenaga Kerja Nomor 260 Tahun 2015. Tidak hanya sekali, sebelumnya Pemerintah juga telah mengeluarkan moratorium yang sama untuk Malaysia (2009) dan Saudi Arabia (2011) atas pertimbangan yang sama yaitu dikarenakan banyaknya jumlah kasus kekerasan yang dialami TKI di negara penempatan, Sehingga moratorium dikeluarkan untuk tujuan melakukan perlindungan TKI di negara-negara yang kerap bermasalah, merendahkan kemanusiaan dan martabat Indonesia di dunia Internasional.

Dampak moratorium tersebut adalah terjadi pergeseran tren negara yang menjadi tujuan PMI khususnya yang berada di Indramayu. Berdasarkan table di atas, dapat di lihat bahwa beberapa negara yang menjadi tujuan PMI di Indramayu adalah negara-negara yang menggunakan bahasa Inggris sebagai bahasa nasionalnya. Hongkong, Malaysia dan Singapura adalah negara-negara yang berbahasa Inggris.

Pada tahun 2017 terdapat 3,905 PMI yang menjadikan Hongkong sebagai negara tujuan. Sementara di tahun 2018 terjadi peningkatan dari tahun sebelumnya menjadi 4,324 PMI yang menjadikan Hongkong sebagai negara tujuan.Sementara itu, Malaysia dan Singapura juga menjadi negara berbahasa Inggris lain yang menjadi tujuan PMI di wilayah Indramayu 2,540 Malaysia tahun 2017 dan Singapura 2,357 tahun 2017. Selanjutnya, pada tahun 2018 jumlah PMI yang menjadikan Malaysia sebagai negara tujuan sebanyak 2,890 dan Singapura 2,893 PMI. Artinya, pada tahun 2017

Sementara itu, program-program pelatihan yang ada di Indramayu tidak banyak yang dilakukan oleh pemerintah bagi CPMI yang akan bekerja ke negara-negara berbahasa Inggris. BLK (Balai Latihan Kerja) Dinas Tenaga Kerja Indramayu merupakan salah satu lembaga yang ada di Dinas Tenaga Kerja Indramayu. BLK berada di lingkungan Dinas Tenaga Kerja yang beralamat di Jl. Jend. Gatot Subroto No. 01 Indramayu 45216 dan Telepon: (0234) 274382Email: support@blkindramayu.com. UPTD ini memberikan layanan pelatihan kerja secara gratis untuk masyakat umum. Hal ini dapat terlihat pada brosur di bawah ini. 


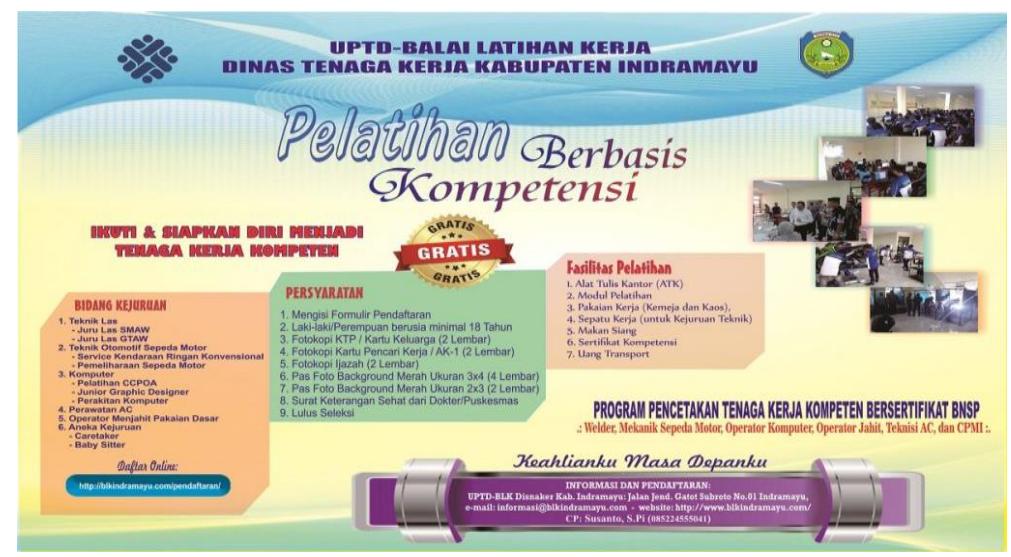

Berdasarkan brosur di atas dapat kita lihat bahwa sampai dengan saat ini, program dalam Balai Latihan Kerja atau BLK antara lain adalah:

1. Juru Las

2. Mekanik Junior Sepeda Motor

3. Operator basic Office

4. Junior Graphic Designer

5. Junior Technical Support

6. Garmen (Menjahit Pakaian Dasar)

7. Eknik Pendingan AC Split

8. Caretaker

Selain BLK yang dibawah Dinas Tenaga Kerja, terdapat juga LPK atau Lembaga Pendidikan Keterampilan yang cukup banyak di wilayah Indramayu. LPK merupakan lembaga yang berdiri untuk merespon adanya program pemerintah $G$ to Gatau Government to Government untuk memenuhi persyaratan Bahasa asing. Berikut adalah contoh-contoh brosur pelatihan bahasa yang dilakukan oleh LPK.
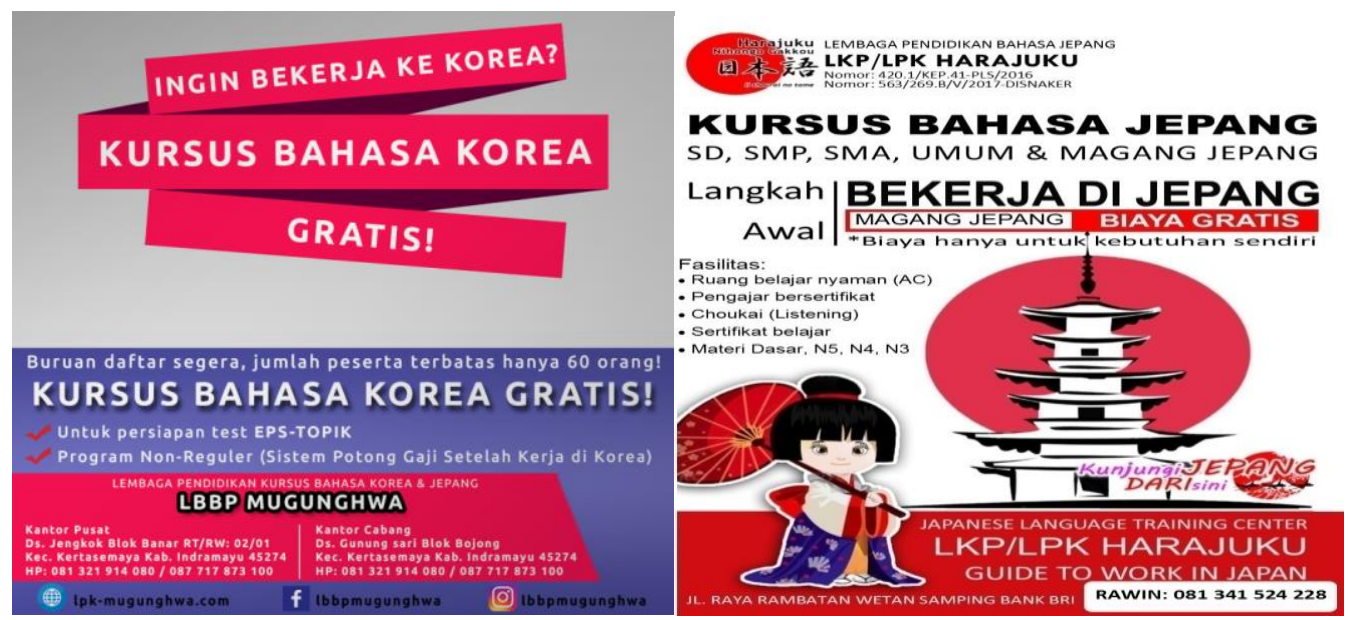

Di awal program pada 2004-2006, penempatan TKI ke Korea Selatan dilakukan oleh Kemenakertrans sebelum Badan Penempatan dan Perlindungan Tenaga Kerja 
Indonesia atau BNP2TKI dibentuk. Namun, sejak tahun 2007 sampai saat ini penempatan TKI ke Korea melalui program G to G dilakukan oleh BNP2TKI.

Program G to G yang ada saat ini adalah untuk Negara Jepang dan Korea. Artinya, persiapan bahasa lebih banyak pada dua bahasa tersebut karena program $G$ to $G$ mensyaratkan kemapuan bahasa. Sementara, untuk Negara lain, termasuk Negara berbahasa Inggris belum ada. Padahal, Calon Pekerja Migran Indonesia atau CPMI yang menjadikan Negara yang berbahasa Inggris sebagai Negara tujuan cukup banyak yaitu 8.801 antara tahun 2017 dan 10.107 pada tahun 2018 berdasarkan data yang diperoleh dari Dinas Tenaga Kerja Indramayu. Angka tersebut lebih tinggi jika dibandingkan dengan jumlah PMI yang bekerja di Korea ataupun Jepang.

Dalam wawancara yang dilakukan dengan Kepala Bagian Penempatan Luar Negeri Dinas Tenaga Kerja Indramayu dikatakan bahwa persiapan bahasa diberikan oleh Perusahaan Penempatan Pekerja Migran Indonesia atau P3MI dahulu bernama PJTKI (Perusahaan Jasa Tenaga Kerja Indonesia (Sukirman, Wawancara. 18 Oktober 2019). Artinya, pemerintah belum memastikan secara langsung persiapan bahasa CPMI atau Calon Pekerja Migran Indonesia sebelum mereka diberangkatkan. Pemerintah menyerahkan persoalan tersebut kepada P3MI sebagai perusahaan swasta yang akan memberangkatkan PMI. Padahal sampai dengan saat ini, kritik terhadap kinerja P3MI masih banyak dilakukan oleh lembaga-lembaga yang konsen terhadap isu pekerja migrant.

Oleh karena itu, penguatan Bahasa Inggris dilakukan di daerah yang banyak PMI karena asumsinya antusiasme masyarakat untuk bekerja di luar negeri kedepan masih cukup tinggi. Hal ini dibuktikan dengan adanya peningkatan jumlah PMI antara tahun 2017-2018. Pelatihan Bahasa Inggris yang dilakukan di Pondok Pesantren AlQur'anniyah dilaksanakan pada santri dengan target jumlah peserta sebanyak 30 peserta.

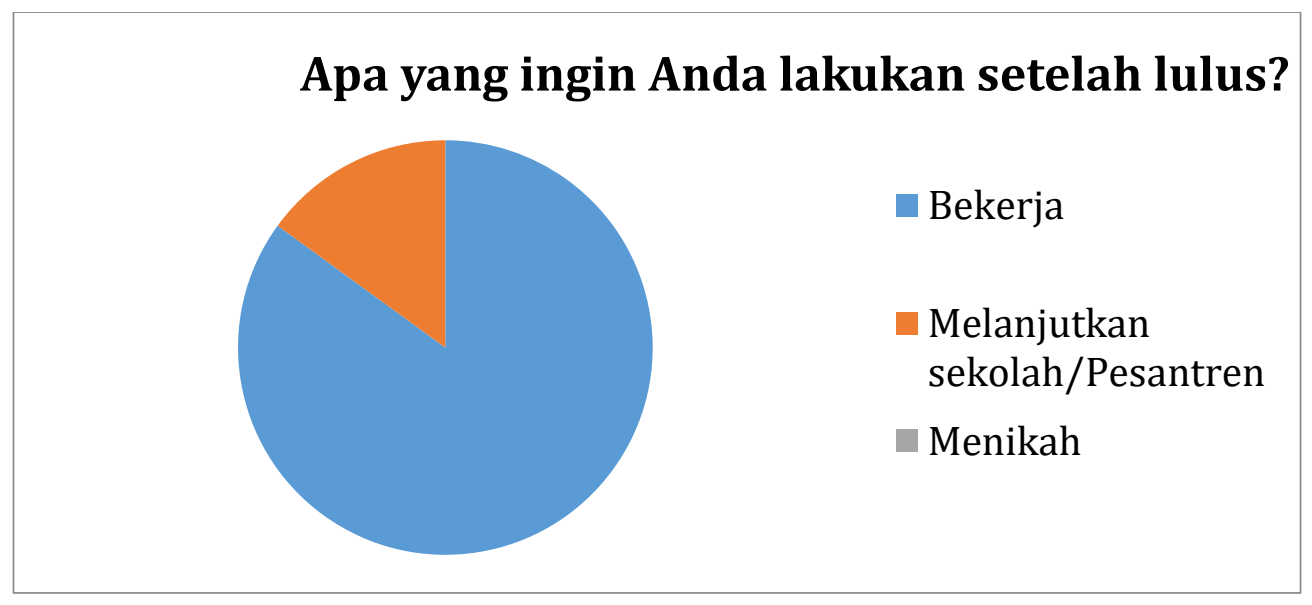


Survey yang dilakukan pada saat tentang apa yang ingin mereka lakukan setelah lulusa sekolah menunjukkan hasil sebanyak 85\% menyatakan mereka akan bekerja setelah mereka lulus dari sekolah. Selanjutnya, 15\% dari mereka menyatakan bahwa mereka ingin melanjutkan sekolah dan $0 \%$ yang menjawab ingin menikah setelah lulus sekolah.

Kemampuan berbahasa Inggris rata-rata peserta masih rendah. Hal ini dibuktikan dengan nilai saat mereka mengikuti tes kemampuan dasar berbahasa Inggris. Meski demikian, sebanyak 85\% peserta menjawab Bahasa Inggris dan hanya 15\% yang menjawab bahasa Arab.

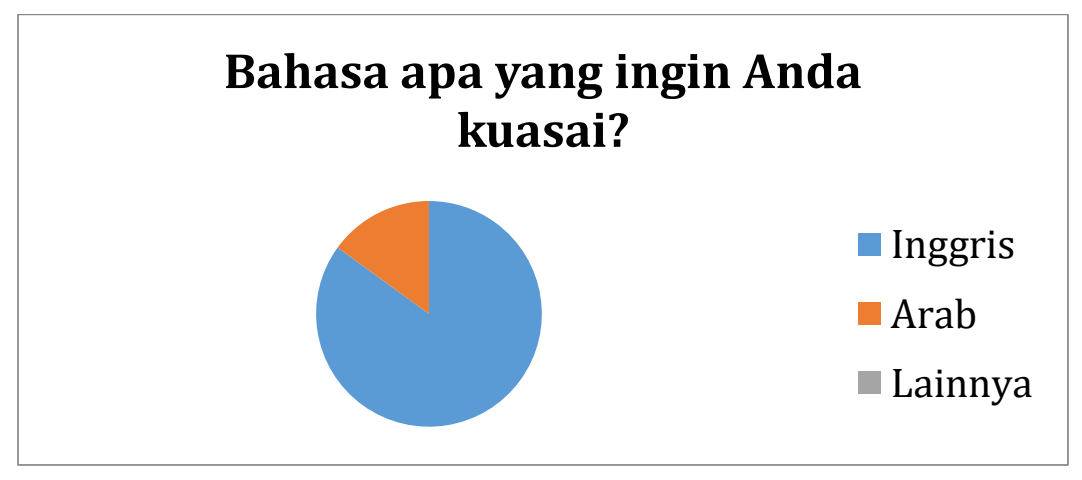

Berdasarkan tes kemampuan dasar peserta. 70\% peserta dapat menjawab dengan baik pertanyaan dasar seperti:

How old are you?

(a). No, I am not (b). I'm 20 (c). I 20

Where are they from?

(a). There are from Indonesia (b) They're from Indonesia (c). I'm from Indonesia

Do you have a brother or sister?

(a). No. I not have (b). No, They don't (c). No, I don't

Hasil penguatan bahasa Inggris selain dampak langsung terdapat juga dampak tidak langsung. Dampak langsung dari kegiatan pendampingan ini adalah adalah adanya 29 siswa di wilayah Indramayu yang memiliki skill bahasa Inggris yang lebih baik dari sebelumnya khususnya terkait topik-topik dasar seperti tentang cara pengenalan diri, berdialog di airport, rumah sakit, dll.

Dampak tidak langsung dari kegiatan ini adalah:

1. Menumbuhkan kesadaran diri siswi-siswi ponpes untuk memiliki ketrampilan sebagai bekal diri.

2. Meningkatkan kesadaran Masyarakat dan pihak Pondok Pesantren tentang persiapan ketrampilan dan kemampuan bahasa bagi mereka yang ingin bekerja di luar negeri. 
Royani Afriani, Maimunah

3. Meningkatkan kesadaran masyarakat penting bahasa Inggris pada saat ini bagi setiap orang tidak hanya bagi mereka yang ingin bekerja di luar negeri.

4. Menumbuhkan semangat belajar bahasa Inggris bagi masyarakat umum dan Pondok Pesantren

\section{KESIMPULAN}

Pelibatan secara langsung dengan dinas terkait seperti Dinas Tenaga Kerja pada kegiatan pengabdian di masyarakat menjadi sangat penting untuk dilakukan karena beberapa hal seperti:

1. Tersedianya data terbaru tentang kondisi PMI dan CPMI di wilayah Indramayu.

2. Tersedianya informasi tentang informasi pelatihan yang disediakan baik oleh pemerintah maupun swasta.

3. Kerjasama antara lembaga pendidikan dan dinas terkait perlu terus diupayakan dibangun agar proses pendampingan menjadi lebih mudah dilakukan dan menyasar secara langsung pada target sasaran

\section{REFERENCES}

https://www.ilo.org/wcmsp5/groups/public/---asia/---ro-bangkok/--ilojakarta/documents/publication/wcms 366944.pdf

https://www.republika.co.id/berita/q1p84r428/bahasa-masih-jadi-kendala pekerjamigran

https://www.republika.co.id/berita/dunia-islam/islam nusantara/14/10/23/ndvkxypondok-pesantren-alquraniyah-krangkeng-bentengi-moral-masyarakat-2habis

Ibad, M,I,. Muthahhari, N,. Ikhtiyarini, P,. Fathulloh,. Maarif, A.B,.and Nuraini. F,. 2013. Buruh migran menggugat: laporan pemantauan keterbukaan informasi publik di sektor migrasi ketenagakerjaan. Yogyakarta: Pusat Sumber Daya Buruh MigranInfest Yogyakarta.

Laporan Tahun 2016, Internasiola Labour Organization (ILO). www.ilo.org

Laporan Tahun 2017, Internasiola Labour Organization (ILO). www.ilo.org

Rahayu, M,D, and Isbandono,P,I. 2010. Pengawasan terhadap PPTKIS (pelaksana penempatan tenaga kerja Indonesia swasta) oleh dinas Tenaga Kerja, Transmigrasi dan Kependudukan Provinsi Jawa Timur: studi pada pra penempatan tenaga kerja Indonesia ke luar negeri. Jakarta: Universitas Negeri Surabaya.

Undang-undang No.18 tahun 2017 tentang Perlindungan Pekerja Migran Indonesia 